\title{
Faktor-Faktor Fundamental Keuangan Perusahaan dan Investment Op- portunity Set Perusahaan Real Estate
}

\author{
Hotma P. Panggabean ${ }^{1}$, Suratno ${ }^{2}$ \\ ${ }^{1}$ Universitas Pancasila, Jl. Srengseng Sawah, Jagakarsa, Jakarta Selatan 12640, \\ ${ }^{2}$ Universitas Esa Unggul, Jalan Arjuna Utara No.9, Kebon Jeruk - Jakarta Barat 11510
}

I N F O A R T I K E L

JEL Classification:

G14

G30

Keywords:

debt to equity ratio, return on equity,

price to book value,

investment opportunity set

\section{$A B S T R A C T$}

Signalling theory assumes that the good company information company will communicate the credibility of the company to the market. Investors assess the company as an entity that has a growing and profitable prospects through investment expected. This study aims to analyze the effect of the fundamental factors for affected investment opportunity set. This study used a sample of 90 years of data from 16 companies property and real estate in the Indonesia Stock Exchange. The results show the level of risk and the book value of equity affected investment opportunity set. but, profitability have no effect on investment opportunity set.

\section{A B S T R A K}

Teori Sinyal (signalling theory) mengasumsikan bahwa informasi baik perusahaan akan mengkomunikasikan kredibilitas perusahaan kepada pasar. Investor menilai perusahaan sebagai entitas yang memiliki pertumbuhan dan prospek menguntungkan melalui investasi yang diharapkan. Penelitian ini bertujuan menganalisis pengaruh faktor fundamental terhadap set kesempatan investasi. Penelitian ini menggunakan sampel 90 data tahun dari 16 perusahaan properti dan real estate di Bursa Efek Indonesia. Hasil penelitian menunjukkan tingkat resiko dan nilai buku saham berpengaruh terhadap set kesempatan investasi. Profitabilitas terbukti tidak berpengaruh terhadap set kesempatan investasi.

\section{Pendahuluan}

Muncul konsep baru dalam menilai suatu perusahaan dengan mengkombinasikan asset yang dimiliki dan opsi investasi di masa depan, yaitu konsep Investment Opportunity Set (IOS). IOS merupakan nilai sekarang dari pilihan-pilihan perusahaan untuk membuat investasi di masa depan. Pilihan-pilihan investasi yang dilakukan perusahaan di masa depan tersebut kemudian dikenal dengan set kesempatan investasi, Kallapur dan Trombley (2001).

Pergerakan serta fenomena indikator ekonomi yang berasal dari faktor fundamental keuangan sebagai faktor yang kecenderunganya menyebabkanterjadinyakenaikandanpenurunan nilai indeks harga saham selalu berpengaruh terhadap tingkat Investment Opportunity Set (IOS) yang diproksikan melalui market to book

*Email Korespondensi: ${ }^{1}$ brianmarvel@yahoo.com, ${ }^{2}$ soeratno_54@yahoo.com 
value of equity (MBVE), merupakan refleksi atas aktifitas perdagangan saham di pasar modal, menjadikanya menarik untuk dianalisis. Penelitian ini menguji pengaruh faktor-faktor fundamental keuangan perusahaan yang diwakili oleh Debt to Equity Ratio(DER), Return on Equity (ROE), dan Price to Book Value (PBV) terhadap Investment Opportunity Set. Penelitian difokuskan pada perusahaan Property dan Real Estate yang terdaftar di Bursa Efek Indonesia selama periode 2007 sampai dengan 2011. Data perubahan market to book value of equity (MBVE) rata-rata pada perusahaan Property dan Real Estate yang terdaftar di BEI pada periode 2007 - 2011, dapat dilihat pada tabel berikut:

\subsection{Signalling Theory}

Teori pensinyalan (signalling theory) mengasumsikan bahwa informasi baik perusahaan akan mengkomunikasikan kredibilitas perusahaan kepada pasar. Menurut signalling theory, pengeluaran investasi memberikan sinyal positif mengenai pertumbuhan perusahaan di masa yang akan datang, sehingga dapat meningkatkan harga saham yang digunakan sebagai indikator nilai perusahaan (Wahyudidan Pawestri, 2006). Pihak manajemen merupakan penyedia informasi dari perusahaan memiliki informasi yang lebih banyak daripada pihak luar atau investor. Oleh

Tabel 1.

IOS, DER, ROE, dan PBV Perusahaan Property dan Real Estate Tahun 2007 -2011

\begin{tabular}{lcccccc}
\hline \multicolumn{1}{c}{ Variabel } & & $\mathbf{2 0 0 7}$ & $\mathbf{2 0 0 8}$ & $\mathbf{2 0 0 9}$ & $\mathbf{2 0 1 0}$ & $\mathbf{2 0 1 1}$ \\
\hline IOS (MBVE) & $\%$ & 224 & 97 & 112 & 130 & 137 \\
DER & $\mathrm{X}$ & 1.32 & 1.24 & 1.20 & 0.99 & 0.93 \\
ROE & $\%$ & 4.24 & 1.65 & 7.12 & 8.48 & 9.42 \\
PBV & $\mathrm{X}$ & 0.01147 & 0.00361 & 0.00398 & 0.00430 & 0.00375 \\
\hline
\end{tabular}

Sumber : Data Bursa Efek Indonesia yang diolah

Set kesempatan investasi merupakan peluang untuk memafaatkan sumber daya perusahaan untuk melakukan ekspansi maupun pengelolaan sumber daya manusia dengan sebaik.baiknya. Investor menilai perusahaan sebagai entitas yang memiliki pertumbuhan dan prospek menguntungkan melalui investasi yang diharapkan. Hal ini dilakukan atas dasar motivasi untuk mendapatkan return yang tinggi. Faktor fundamental mencerminkan kinerja operasional perusahaan. Faktor tingkat resiko, profitabilitas dan nilai buku saham diduga sebagai beberapa faktor yang mampu meningkatkan set kesempatan investasi. Riset ini berupaya membuktikan pengaruh faktor fundamental terhadap set kesempatan investasi pada suatu perusahaan.

\section{Telaah Teori dan Pengembangan Hipotesis}

karena itu, terjadi asymmetric information antara pihak manajemen perusahaan dan investor karena ketidakpercayaan investor terhadap informasi yang telah disajikan. Signalling theory merupakan penjelasan dari asimetri informasi. Asimetri informasi adalah kondisi dimana suatu pihak memiliki informasi yang lebih banyak daripada pihak lain. Misalnya, pihak manajemen perusahaan memiliki informasi yang lebih banyak dibandingkan dengan pihak investor di pasar modal.

Perusahaan dapat memberikan sinyal tentang pertumbuhan perusahaan dengan memberikan informasi tentang kebijakan dividennya. Dividen dengan jumlah besar akan memberikan sinyal positif tentang pertumbuhan perusahaan. Tetapi informasi dividen yang tinggi dapat pula memberikan sinyal dan informasi lain kepada para investor bahwa perusahaan sebenarnya tidak mengalami pertumbuhan. 
Oleh karena itu jumlah dividen dipertinggi untuk menarik minat investor.

Informasi yang diterima tersebut dapat direspons secara berbeda oleh investor. Perusahaan yang memiliki kondisi fundamental yang terpercaya dapat dibedakan dari perusahaan yang memiliki kondisi fundamental kurang terpercaya dengan mengirimkan sinyal ke pasar modal. Sinyal dari perusahaan yang kondisi fundamentalnya terpercaya tentu akan direspons oleh investor, sehingga sinyal tersebut menjadi berkualitas. Sedangkan sinyal yang dikirim oleh perusahaan yang kondisi fundamentalnya kurang terpercaya tentu tidak akan dapat menyamai sinyal yang dikirim oleh perusahaan yang kondisi fundamentalnya terpercaya (Bhattacharya \& Dittmar, 2001 dalam Hendrawijaja, 2009).

Manajer pada umumnya termotivasi untuk menyampaikan informasi yang baik mengenai kondisi perusahaan kepada masyarakat luas karena melalui penyampaian informasi tersebut dapat meyakinkan masyarakat untuk menanamkan modalnya di perusahaan tersebut. Pihak luar tentunya hanya memiliki informasi yang minimal mengenai kebenaran dari informasi yang disampaikan tersebut. Jika manajer dapat memberikan sinyal yang meyakinkan kepada publik (tentunya harus didukung oleh data yang mendasarinya), maka publik juga akan merespons secara positif.

Kurangnya informasi yang diterima oleh pihak luar mengenai kondisi perusahaan akan menyebabkan pihak investor cenderung untuk melindungi kepentingan mereka dengan memberikan harga yang rendah terhadap nilai perusahaan. Pihak manajemen sebagai pengelola, dapat meningkatkan nilai perusahaan dengan mengurangi asimetri informasi yang terjadi pada investor. Salah satu cara untuk mengurangi distorsi informasi tersebut yaitu dengan memberikan sinyal kepada pihak luar melalui informasi keuangan yang terpercaya dan disampaikan tepat waktu, hal ini dapat dipercaya akan mengurangi ketidakpastian mengenai prospek dan resiko perusahaan yang akan datang (Wolk et al, 2000).Sebagian invertor berasumsi bahwa perusahaan yang menjual saham dipasar modal, adalah perusahaan yang mempunyai prospek yang kurang menguntungkan, sehingga pemilik perusahaan mencari sumber dana dan juga berbagi resiko investasi dengan pihak investor. Perusahaan yang mempunyai prospek yang baik, akan mendanai perusahaan dari pinjaman, sehingga seluruh keuntungan yang didapat dapat dinikmati seluruhnya oleh pemegang saham. Sedangkan disisi lain, perusahaan yang go public akan lebih mudah bagi investor untuk megawasi dan mengetahui kinerja serta kelemahan perusahaan yang ada, karena perusahaan lebih dituntut untuk melakukan keterbukaan informasi, sebagai salah satu syarat dan konsekwensi perusahaan yang go-public dipasar ekuitas, sehingga pengelolaan yang dilakukan oleh manajemen akan lebih akuntibel dan transparan, hal ini akan lebih memudahkan investor untuk melakukan keputusan investasi dibandingkan dengan perusahaan yang tidak tercatat dipasar modal, yang informasinya terkadang sangat sulit untuk didapatkan.

\subsection{Hubungan antara Faktor Fundamental dengan Investment Opportunity Set}

Investasi merupakan kekuatan penggerak utama dari setiap sistem usaha. Keputusan investasi maupun disinvestasi suatu perusahaan harus dapat disesuaikan dengan kebutuhan, karakteristik operasi dan dapat diterima perusahaan. Salah satu parameter penting dalam laporan keuangan yang digunakan untuk menentukan investasi adalah kombinasi aktiva dan opsi investasi di masa yang akan datang dan diukur dengan IOS yang akan menunjukkan nilai suatu perusahaan (Gumanti dan Puspitasari, 2008). Investor akan menilai apakah perusahaan memiliki pertumbuhan dan prospek menguntungkan melalui investasi yang diharapkan nantinya investor akan mendapatkan return yang tinggi.

Analisis fundamental adalah metode analisis yang didasarkan pada fundamental ekonomi suatu perusahaan. Teknis ini menitik 
beratkan pada rasio finansial dan kejadian kejadian yang secara langsung maupun tidak langsung memengaruhi kinerja keuangan perusahaan. Sebagian pakar berpendapat teknik analisis fundamental lebih cocok untuk membuat keputusan dalam memilih saham perusahaan mana yang dibeli untuk jangka panjang. analisis fundamental dibagi dalam tiga tahapan analisa yaitu analisis ekonomi, analisis industri, dan anaslisis perusahaan.

Analisis fundamental keuangan merupakan alat analisis yang dapat mengidentifikasi kekuatan serta kelemahan keuangan suatu perusahaan atau organisasi dimasa lampau, pada saat ini dan dimasa yang akan datang. Didalam menganalisis laporan keuangan dapat menggunakan dua macam cara perbandingan (Riyanto, 1990), yaitu:

1. Membandingkan rasio sekarang dengan rasio-rasio pada waktu yang lampau, atau dengan rasio-rasio yang dapat diperkirakan pada masa yang akan datang pada perusahaan yang sama.

2. Membandingkan rasio-rasio yang sama dari perusahaan atau industri yang sejenis untuk periode atau waktu yang sama.

Fundamental keuangan perusahaan, menurut kegunaan, tujuan dan sebagai alat analisa, pada umumnya dapat dikategorikan kedalam lima jenis kelompok (Harmono, 2009), yaitu:

1. Rasio Likuiditas (liquidity ratios), yaitu rasio keuangan yang meng-identifikasi serta mengukur guna mengetahui kemampuan perusahaan membayar kewajiban jangka pendeknya.

2. Rasio Solvabilitas (solvability ratios), yaitu rasio keuangan yang dapat mengidentifikasi serta mengukur kemampuan perusahaan untuk memenuhi kewajiban jangka panjangnya.

3. Rasio Profitabilitas atau Rentabilitas(profitability or rentability ratios), yaitu rasio keuangan yang mengidentifikasi dan mengukur kemampuan perusahaan menghasilkan laba dengan penjualan maupun investasi.

4. Rasio Aktifitas (activity ratios), yaitu analisis keuangan yang meng-identifikasi serta mengukur seberapa efektif dan efisien perusahaan mengelola sumber dana yang tersedia.

5. Rasio Pasar (Market ratios), yaitu analisis keuangan yang meng-identifikasi serta mengukur harga pasar saham relatif terhadap nilai bukunya.

IOS adalah hubungan antara pengeluaran saat ini maupun di masa yang akan datang dengan nilai, return atau prospek sebagai hasil dari keputusan investasi untuk menghasilkan nilai perusahaan. Menurut Hasnawati (2005), IOS adalah suatu kombinasi antara aktiva yang dimiliki dan pilihan investasi di masa yang akan datang dengan net present value positif.

IOS merupakan variabel yang tidak dapat diobservasi karena IOS menggambarkan tentang luasnya kesempatan atau peluang investasi bagi suatu perusahaan, namun sangat tergantung pada pilihan expenditure perusahaan untuk kepentingan di masa yang akan datang (Norpratiwi, 2007). Menurut Kallapur dan Trombley (1999), proksi IOS dapat diklasifikasikan dalam tiga tipe, yaitu:

1. Proksi berbasis harga.

Proksi ini didasarkan pada perbedaan antara aset dan nilai perusahaan. Oleh karena itu proksi ini sangat bergantung pada harga saham seperti rasio market value of equity plus book value of debt $(\mathrm{V})$, ratio of book to market value of asset $(A / V)$, ratio of book to market value of equity (BE/MVE), ratio of book value of property, plant, and equipment to firm value (PPE/V), ratio of replacement value of assets to market value (Tobin-q), ratio of depreciation expense to value (DEP/V), dan earning price ratio.

2. Proksi berbasis investasi.

Proksi ini menunjukkan tingkat aktivitas investasi yang tinggi secara positif berhubungan dengan IOS perusahaan. Perusahaan dengan IOS yang tinggi juga akan mempunyai tingkat investasi yang 
sama tinggi, yang dikonversi menjadi aset yang dimiliki. Proksi IOS berbasis investasi mencakup ratio $R \& D$ expense to firm value $(\mathrm{R} \& \mathrm{D} / \mathrm{V})$, ratio of $R \& D$ expense to total assets $(\mathrm{R} \& \mathrm{D} / \mathrm{A})$, ratio of $R \& D$ expense to sales $(\mathrm{R} \& \mathrm{D} / \mathrm{S})$, ratio of cappital addition to firm value $(\mathrm{CAP} / \mathrm{X})$, ratio of capital addition to asset book value (CAPX/A).

3. Proksi berbasis pada varian.

Proksi ini didasarkan pada pemikiran bahwa pilihan akan menjadi lebih bernilai sebagai variabilitas dari return dengan mendasarkan pada peningkatan aset. Proksi IOS berdasarkan varian yaitu, variance of total return (VARRET), dan market model beta.

Ketiga jenis proksi di atas yang menggambarkan beragamnya ukuran IOS memungkinkan beberapa peneliti menggunakan beragam rasio sebagai proksi IOS. Hal ini terjadi karena IOS bersifat unobserable (Gaver dan Gaver 1993). Pendekatan yang digunakan beberapa peneliti sebagian besar menggunakan ukuran variabel rasio-rasio dalam bentuk pengukuran rasio tunggal (single ratio), namun demikian beberapa penelitian lainnya menggunakan pendekatan pengukuran komposit (composit measures) yaitu menggabungkan beberapa rasio sehingga membentuk suatu ukuran baru sebagai proksi IOS.

Putu Terestiani Dadri (2011) melakukan penelitian tentang Pengaruh Investment Opportunity Set (IOS) dan Struktur Modal terhadap Return Saham pada Perusahaan Farmasi di Bursa Efek Indonesia. Hasil penelitiannya menunjukkan bahwa IOS (MV/ BVA, MV/BE, E/P, CA/BVA, CA/MVA), DER berpengaruh positif dan signifikan terhadap Return Saham. DER mempunyai pengaruh tidak signifikan terhadap Return Saham. Saragih (2009) melakukan penelitian tentang Pengaruh Profitability dan Investment Opportunity Set terhadap Dividen Tunai Pada Perusahaan Terbuka di Bursa Efek Indonesia. Penelitiannya menunjukkan bahwa secara parsial hanya variabel ROE dan NPM, yang mempunyai pengaruh positif dan signifikan terhadap dividen tunai, sedangkan variabel bebas lain yaitu $M V A$ / BVA (Market to Book Value of Assets), dan Property, Plan \& Equipment to the Book Value of Assets (PPE/BVA) tidak mempunyai pengaruh yang signifikan terhadap dividen tunai.

Evana (2009) melakukan penelitian tentang Analisis Hubungan Investment Opportunity Set (IOS) berdasarkan Nilai Pasar dan Nilai Buku dengan Realisasi Pertumbuhan. Penelitiannya menunjukkan bahwa adanya korelasi positif signifikan antara IOS dengan realisasi pertumbuhan aktiva, ekuitas dan penjualan. Suratno (2005) melakukan penelitian tentang Pengaruh SetPeluang Investasi,Asimetri Informasi, Manajemen Aset, Pengungkit dan Kepemilikan Manajerial terhadap Pertumbuhan Terealisasi serta Implikasinya Pada Nilai Nilai Perusahaan. Hasil penelitiannya menunjukkan terbukti bahwa Set Peluang Investasi (IOS) berpengaruh secara signifikan terhadap pertumbuhan terealisasi (realized growth).

Hamzah (2005) melakukan penelitian tentang Analisis Rasio Likuiditas, Profitabilitas, Aktivitas, Solvabilitas, dan Investment Opportunity Set (IOS) Dalam Tahapan Siklus Kehidupan Perusahaan Manufaktur Yang Terdaftar di Bursa Efek Indonesia Tahun 2001-2005. Penelitiannya menunjukkan bahwa IOS berpengaruh secara signifikan pada tahap pendirian, ekspansi awal, sedangkan pada tahap akhir, kedewasaan, dan penurunan tidak berpengaruh secara signifikan. Gagaring Pagalung (2003) melakukan penelitian tentang Pengaruh Kombinasi Keunggulan dan Keterbatasan Perusahaan terhadap Investment Opportunity Set (IOS). Hasil penelitiannya menunjukkan bahwa Kombinasi Keunggulan dan Keterbatasan Perusahaan berpengaruh positif dan signifikan terhadap Investment Opportunity Set (IOS). 
Gambar 1

Kerangka Pikir

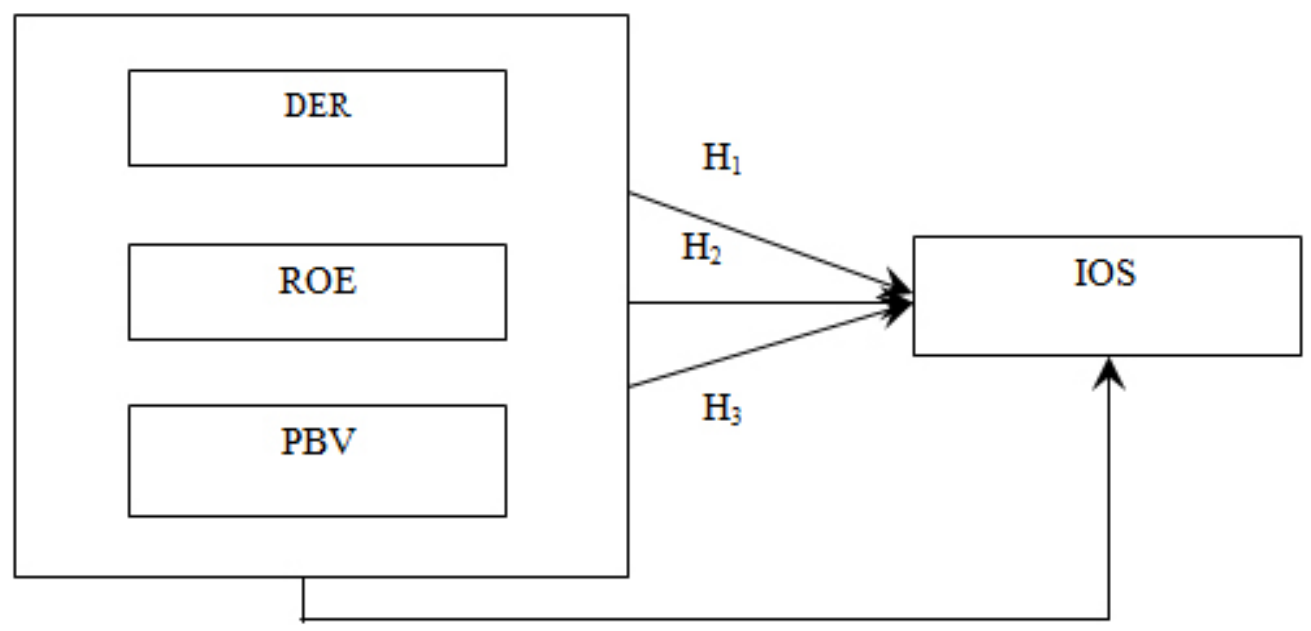

Berdasarkan kajian teori dan beberapa riset sebelumnya, maka hipotesis penelitian pada penelitian ini adalah:

$$
\begin{array}{rlr}
\mathrm{H}_{1}: & \text { DebttoEquityRatio(DER) } & \text { berpengaruh } \\
& \text { signifikan terhadap } r \text { Investment } \\
& \text { Opportunity Set (IOS). } \\
\mathrm{H}_{2}: & \text { Return on equity (ROE) } & \text { berpengaruh } \\
& \text { signifikan terhadap } r \text { Investment } \\
& \text { Opportunity Set (IOS) } \\
\mathrm{H}_{3}: & \text { Price to Book Value (PBV) berpengaruh } \\
& \text { signifikan terhadap } \\
& \text { Opportunity Set (IOS). }
\end{array}
$$

\section{Metode Penelitian}

Data penelitian ini berupa laporan keuangan publikasian tahunan yang telah diaudit selama tahun 2007 - 2011. Penelitian ini menggunakan data sekunder, yaitu data yang diperoleh secara tidak langsung dari sumbernya, dengan mengutip dari laporan keuangan perusahaan sampel dan ICMD (Indonesia Capital Market Directory). Data yang digunakan merupakan gabungan antara data time series and cross section.

Teknik pengambilan sampel menggunakan metode purposive sampling yaitu pengambilan sampel berdasarkan kepada criteria tertentu yang dikehendaki peneliti. Kriteria sampel dalam penelitian ini adalah sebagai berikut : 1) Perusahaan Property dan
Real Estate yang berturut-turut terdaftar di Bursa Efek Indonesia dan mempublikasikan laporan keuangan selama periode pengamatan dari tahun 2007-2011. 2) Perusahaan-perusahaan yang secara terus menerus terdaftar dalam periode penelitian sebanyak 25 perusahaan. 3) Data yang digunakan dasar penghitungan adalah data tahunan, baik Market to book Value Equity, Debt to Equity Ratio, Return on Equity, maupun Price to Book Value selama periode yang diteliti. 4) Laporan Keuangan disajikan dalam mata uang rupiah.

Berdasarkan hipotesis dalam penelitian ini maka metode analisis data yang digunakan adalah analisis kuantitatif. Analisis kuantitatif adalah suatu pengukuran yang digunakan dalam suatu penelitian yang dapat diuntungkan dengan jumlah satuan tertentu atau dinyatakan dengan angka-angka. Analisis ini meliputi pengolahan data, pengorganisasian data dan penemuan hasil. Pengujian data yang dilakukan dalam penelitian ini adalah dengan menggunakan model regresi.

Metode analisis yang digunakan untuk menguji hipotesis adalah regresi linier berganda sebagai berikut :

$\mathrm{Y}=\alpha+\beta_{1} \mathrm{DER}+\beta_{2} \mathrm{CFO}+\varepsilon$

Dalam hal ini :

$\mathrm{Y} \quad=$ Investment Opportunity Set (IOS)

A $\quad=$ Konstanta

$\beta_{1}-\beta_{2}=$ Koefisien regresi 


$$
\begin{array}{ll}
\text { DER } & =\text { Debt Equity Ratio } \\
\mathrm{CFO} & =\text { Cash Flow Operational } \\
\mathrm{E} & =\text { Error }
\end{array}
$$

\section{Hasil Penelitian dan Pembahasan}

Analisa data dalam penelitian ini menggunakan sampel sebanyak 16 perusahaan yang dipilih dengan metode purposive sampling, dengan kriteria yang ditetapkan. Ringkasan proses pemilihan sampel disajikan pada table berikut:
Dari Gambar 1, dapat dilihat bahwa data menyebar di sekitar garis diagonal dan mengikuti arah garis diagonal, maka dapat disimpulkan bahwa data residual terdistribusi dengan normal.

Uji Multikolinearitas berarti adanya hubungan linear yang sempurna atau pasti, di antara beberapa atau semua variabel yang menjelaskan dari model regresi.

\section{Proses Pemilihan Sampel}

\begin{tabular}{lc}
\hline \multicolumn{1}{c}{ Uraian } & Jml Persh \\
\hline $\begin{array}{l}\text { Perusahaan Property dan Real Estate yang terdaftar di BEI (Populasi Penelitian) } \\
\text { di tahun 2011 }\end{array}$ & 50 \\
Laporan keuangan tidak tersedia selama lima tahun berturut-turut, dari tahun & -25 \\
2007 sampai dengan tahun 2011 & -9 \\
Sebagai Outlier atas data secara keseluruhan & 16 \\
Perusahaan yang terpilih menjadi sampel (yang memenuhi kriteria penentuan & \\
sampel) & \\
\hline
\end{tabular}

Uji asumsi klasik dilakukan untuk mendeteksi gejala penyakit asumsi klasik. Pengujian yang dilakukan mencakup uji normalitas, multikolinearitas, heteroskedastisitas, dan uji autokorelasi. Kriteria normal ditentukan jika data menyebar di sekitar garis diagonal dan mengikuti arah garis diagonal menunjukkan pola distribusi normal maka model regresi memenuhi asumsi normalitas. Berikut adalah gambar normalitas data setelah dilakukan outlier:

\section{Gambar 1}

Grafik Normalitas $\mathbf{P}$ - P plot

Perusahaan Property dan Real Estate Tahun 2007-2011

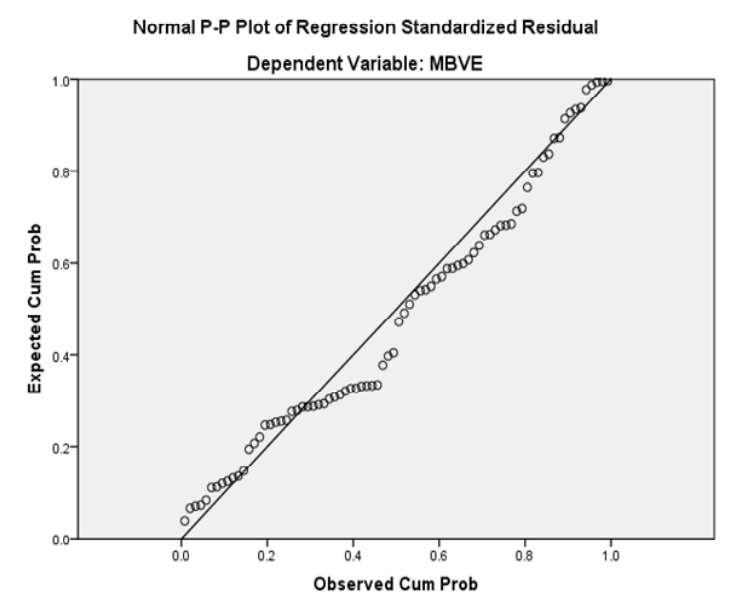

Sumber: Data Bursa Efek Indonesia yang diolah
Untuk adanya gejala multikolinearitas pada model regresi diuji dengan menggunakan Variance Inflation Factor (VIF). Multikolinearitas terjadi apabila nilai VIF $\geq$ 10. Hasil pengujian multikolinearitas dalam penelitian ini ditunjukkan dalam tabel berikut ini:

Tabel 3.

Hasil Uji Multikolinearitas

Coefficients $^{\mathrm{a}}$

\begin{tabular}{clrr}
\hline \multirow{2}{*}{ Model } & \multicolumn{2}{c}{ Collinearity Statistics } \\
& Tolerance & \multicolumn{1}{c}{ VIF } \\
\hline \multirow{2}{*}{1} & DER (X1) & .931 & 1.074 \\
& ROE (X2) & .931 & 1.074 \\
& PBV (X3) & .997 & 1.003 \\
\hline
\end{tabular}

a. Dependent Variable: MBVE

Sumber: Data Bursa Efek Indonesia yang diolah

Berdasarkan tabel diatas diketahui bahwa semua variabel bebas yaitu DER, ROE, dan PBV mempunyai nilai VIF $<10$. Hal ini dapat disimpulkan bahwa variabel independen DER, ROE, dan PBV tidak memiliki masalah multikolinearitas.

Uji heteroskedastisitaas dilakukan dengan analisis grafik, tampak pada gambar di 
bawah ini:

\section{Gambar 2}

\section{Scatter Plot Perusahaan Property dan Real Estate}

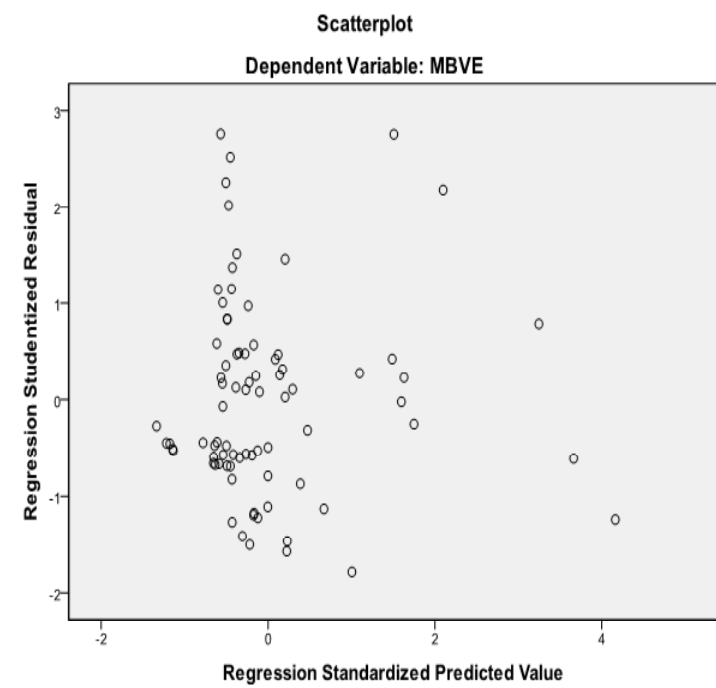

Dari gambar diatas dapat diketahui bahwa tidak ada pola yang jelas, serta titik-titik menyebar di atas dan di bawah angka 0 pada sumbu Y, maka tidak terjadi heteroskedastisitas.

Uji autokorelasi digunakan untuk mengetahui ada tidaknya hubungan antar kesalahan pengamatan atau error residual. Untuk mengetahui ada tidaknya autokorelasi ini digunakan uji Durbin Watson (DW). Berdasarkan olah data dengan menggunakan SPSS, hasil uji autokorelasi dapat dilihat pada tabel di bawah ini.

Tabel 4. Uji Autokorelasi

\begin{tabular}{cc}
\hline Model & Durbin - Watson \\
\hline 1 & $1.614^{\mathrm{a}}$ \\
\hline
\end{tabular}

Sumber: Data Bursa Efek Indonesia yang diolah

Dari Tabel 4. di atas menunjukkan nilai Durbin Watson yang dihasilkan dari model regresi diperoleh nilai 1.614. Pengujian dikatakan bebas autokorelasi jika berada pada rentang $d_{\mathrm{U}}$ sampai $4-d_{\mathrm{U}}$. Penentuan nilai $d_{\mathrm{U}}$ diperoleh dari tabel Durbin Watson. Pada tingkat kesalahan 0,05 dan jumlah data (n) sebesar 80, dan $\mathrm{k}$ adalah 3 (k adalah jumlah variable independen) diperoleh nilai $d_{L}=1.5600$ nilai $d_{\mathrm{U}}$ sebesar 1.7153. Jadi $4-d_{\mathrm{U}}=2,2847$ dan $4-d_{L}=2.4400$. Karena nilai Durbin Watson 1.614 berada pada daerah antara $d_{L}$ dan $d_{\mathrm{U}}$ maka hasilnya tidak dapat disimpulkan.

Analisis model pada penelitian ini dilakukan dengan menggunakan uji regresi linier berganda. Uji ini dipilih karena bertujuan untuk mengetahui pengaruh variabel bebas yang berjumlah lebih dari 1 terhadap variabel terikat. Variabel bebas pada penelitian ini adalah Debt to Equity Ratio (DER), Return on Equity (ROE), dan Price to Book Value (PBV). Sedangkan variable terikat adalah Investment Opportunity Set (MBVE).

1. Analisis Regresi Berganda

Berikut adalah hasil uji regresi linier berganda yang menguji pengaruh variabel bebas yang terdiri dari DER, ROE, dan PBV terhadap IOS selengkapnya:

Berdasarkan hasil perhitungan regresi diatas maka dapat dirumuskan persamaan regresi sebagai berikut:

\section{$\mathrm{MBVE}=45.966+0.154$ DER $-0.631 \mathrm{ROE}+$ 55.806 PBV + e}

Penjelasan persamaan tersebut sebagai berikut:

1. Konstanta sebesar 45.966; artinya jika DER, ROE, dan PBV nilainya 0, maka MBVE nilainya sebesar 45.966.

2. Koefisien regresi variabel DER sebesar 0.154; artinya jika DER mengalami kenaikan 1 satuan, maka MBVE akan mengalami kenaikan sebesar 0.154 satuan.

3. Koefisien regresi variabel ROE sebesar - 0.631; artinya jika ROE mengalami kenaikan 1 satuan, maka MBVE akan mengalami penurunan sebesar 0.631 satuan.

4. Koefisien regresi variabel PBV sebesar 55.806; artinya jika PBV mengalami kenaikan 1 satuan, maka MBVE akan mengalami kenaikan sebesar 55.806 satuan.

Hasil uji F dengan menggunakan SPSS, diperoleh hasil uji F (Simultan) bahwa nilai $\mathrm{F}_{\text {hitung }}$ adalah sebesar 63.586. 
Sedangkan nilai $\mathrm{F}_{\text {tabel }}$ dapat dilihat pada tabel statistik F (pada taraf signifikansi $\alpha=5 \%$ dan derajat bebas $\mathrm{db}_{1}=\mathrm{k}$ dan $\mathrm{db}_{2}=\mathrm{n}-\mathrm{k}-1$ ), atau $\mathrm{db}_{1}=3$ dan $\mathrm{db}_{2}=80-3-1=76$. Diperoleh nilai $\mathrm{F}$ tabel $=2,72$. Karena nilai $F_{\text {hitung }}>F_{\text {tabel }}(63,586$ $>2,72$ ) maka dapat disimpulkan bahwa semua variabel independen (DER, ROE, dan PBV) secara bersama-sama berpengaruh signifikan terhadap variabel dependen MBVE. Hal ini berarti model penelitian yang duji adalah model yang baik (fit).

Hasil uji koefisien determinasi diperoleh hasil uji nilai Adjusted $R$ Square (Adjusted $R^{2}$ ) sebesar 0.704 (70\%). Jadi kontribusi pengaruh semua variabel independen (DER, ROE, dan PBV) terhadap variabel dependen MBVE adalah sebesar $70 \%$. Sedangkan sisanya sebesar $30 \%$ dipengaruhi oleh variabel lain yang tidak diteliti. Hal ini juga menunjukkan bahwa pengarh 3 varibel independen yang diuji sanagt kuat terhadap set kesempatan invstasi. Berikut adalah hasil Uji t DER, ROE, dan PBV terhadap MBVE.
3. Variabel ROE tidak berpengaruh secara signifikan terhadap variabel MBVE. Hal ini karena ROE memiliki $t_{\text {hitung }}$ lebih kecil daripada $t_{\text {tabel }}(1.665)$.

Berdasarkan hasil uji t yang dilakukan, hipotesis pertama yang menyatakan bahwa Debt to Equity Ratio (DER) memiliki pengaruh secara signifikan terhadap Investment Opportunity Set (MBVE) diterima. Artinya, Debt to Equity Ratio $(D E R)$ berpengaruh secara signifikan terhadap Investment Opportunity Set (MBVE).

Hasil penelitian ini sesuai dengan pendapat Brigham dan Houston (2001) bahwa peningkatan hutang diartikan oleh pihak luar tentang kemampuan perusahaan untuk membayar kewajiban di masa yang akan datang atau adanya risiko bisnis yang rendah, hal tersebut akan direspon secara positif oleh pasar.

Terdapat dua pandangan mengenai keputusan pendanaan. Pandangan pertama dikenal dengan pandangan tradisional yang

\section{Coefficients $^{\mathrm{a}}$}

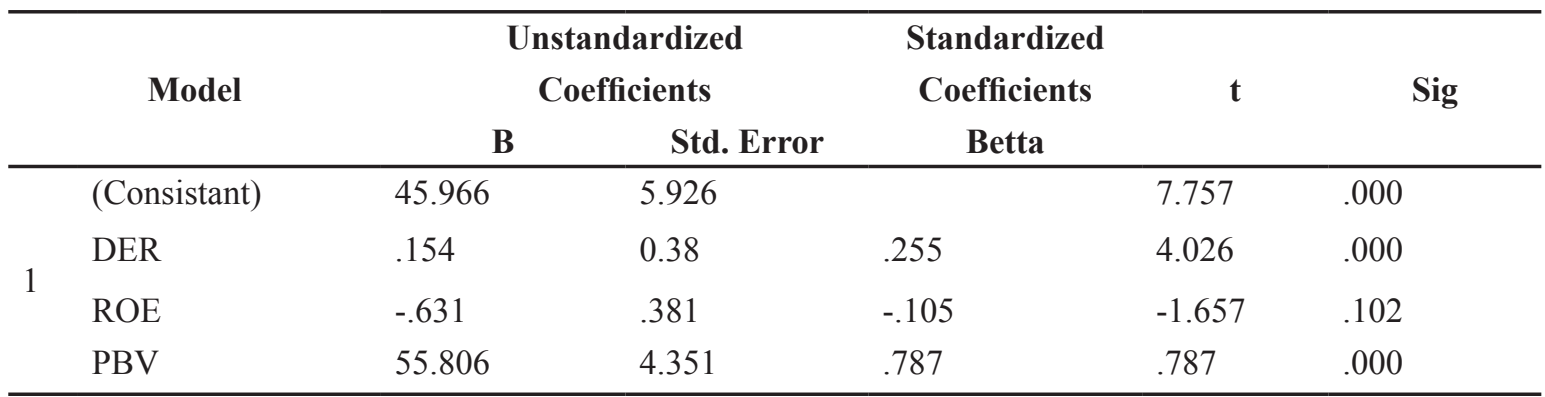

a. Dependent Variable: MBVE

Nilai $\mathrm{t}_{\text {tabel }}$ dapat dilihat pada tabel statistik $\mathrm{t}$ (pada taraf signifikansi $\alpha=5 \%: 2=0,025$ (uji 2 sisi) dan derajat bebas $\mathrm{db}=\mathrm{n}-\mathrm{k}-1$ ), atau $\mathrm{db}=$ 80-3-1 $=76$. Diperoleh nilai $t_{\text {tabel }}$ sebesar 1,665. Dari hasil uji t dapat disimpulkan sebagai berikut:

1. Variabel DER berpengaruh secara signifikan terhadap variabel MBVE. Hal ini karena $\mathrm{t}_{\text {hitung }}>\mathrm{t}_{\text {tabel }}(4.026>1.665)$.

2. Variabel PBV berpengaruh secara signifikan terhadap variabel MBVE. Hal ini karena $\mathrm{t}_{\text {hitung }}>\mathrm{t}_{\text {tabel }}(12.826>1.665)$. menyatakan bahwa struktur modal mempengaruhi nilai perusahaan. Pandangan tradisional diwakili oleh dua teori yaitu Trade off Theory dan Pecking Order Theory. Pandangan kedua dikemukakan oleh Modigliani dan Miller (1958) yang menyatakan bahwa struktur modal tidak mempengaruhi nilai perusahaan.

Masulis (1980) melakukan penelitian dalam kaitannya dengan relevansi keputusan pendanaan, menemukan bahwa terdapat kenaikan abnormal returns sehari sebelum dan sesudah pengumuman peningkatan proporsi hutang, sebaliknya terdapat penurunan abnormal returns pada saat perusahaan mengumumkan 
penurunan proporsi hutang. Fama dan French (1998) menemukan bahwa investasi yang dihasilkan dari leverage memiliki informasi yang positif tentang perusahaan di masa yang akan dating. Hal ini menunjukkan bahwa kebijakan pendanaan berpengaruh terhadap IOS.

Berdasarkan hasil uji t yang dilakukan, hipotesis kedua yang menyatakan bahwa Return on equity (ROE) memiliki pengaruh secara signifikan terhadap Investment Opportunity Set (MBVE) ditolak. Artinya, Return on equity (ROE) tidak berpengaruh signifikan terhadap Investment Opportunity Set (MBVE). Investment Opportunity Set (MBVE) yang tinggi tidak selalu diikuti dengan Return on equity (ROE) yang naik karena dalam perusahaan Property dan Real Estate, investor tidak melihat keuntungan jangka pendek tetapi melihat berdasarkan prospek jangka panjang.

Berdasarkan hasil uji t yang dilakukan, hipotesis ketiga yang menyatakan bahwa Price to BookValue $(P B V)$ memiliki pengaruh secara signifikan terhadap Investment Opportunity Set (MBVE) diterima. Artinya, Price to BookValue $(P B V)$ berpengaruh signifikan terhadap Investment Opportunity Set (MBVE). Semakin tinggi Price to BookValue (PBV) suatu perusahaan menunjukkan bahwa nilai pasar saham lebih besar daripada nilai bukunya. Hal ini akan berpengaruh positif terhadap harga saham dari perusahaan bersangkutan. Semakin tinggi dana yang ditanamkan oleh investor cenderung akan meningkatkan harga saham, dan dengan demikian meningkatkan Investment Opportunity Set (MBVE).

Hasil penelitian ini menunjukkan bahwa faktor fundamental perusahaan yang berasal dari laporan keuangan dan direpresentasikan oleh Debt to equity ratio (DER), Return on equity (ROE), dan Price to book value (PBV) secara bersama-sama memberikan sinyal yang positif bagi investor untuk memprediksi kinerja perusahaan di masa mendatang sehingga menjadi pertimbangan investor untuk memilih saham suatu perusahaan. Semakin baik kinerja perusahaan, investor semakin berminat untuk menanamkan investasinya dalam suatu perusahaan. Sampai level tertentu, hal ini akan meningkatkan harga saham dan berakibat meningkatnya Investment Opportunity Set (MBVE).

\section{Simpulan, Keterbatasan dan Implikasi Hasil Penelitian}

Berdasarkan hasil analisis yang telah dilakukan dapat diambil kesimpulan sebagai berikut : 1) secara simultan variabel independen Debt to equity ratio, Return on equity, dan Price to Book Value) berpengaruh signifikan terhadap Investment Opportunity Set (pada perusahaan Property dan Real estate yang terdaftar di Bursa Efek Indonesia selama periode 2007 sampai dengan 2011.2) Debt Equity Ratio (DER) secara parsial memiliki pengaruh yang signifikan terhadap Investment Opportunity Set (MBVE). Hipotesis kedua $\left(\mathrm{H}_{2}\right)$ yang menyatakan bahwa Debt Equity Ratio (DER) memiliki pengaruh yang signifikan terhadapInvestment Opportunity Set (MBVE) diterima. Hal ini menunjukkan bahwa semakin tinggi Debt Equity Ratio (DER) suatu perusahaan akan meningkatkan daya tarik investor untuk menanamkan dananya ke dalam perusahaan sehingga harga saham akan relatif meningkat, dan dengan demikian dapat meningkatkan Investment Opportunity Set (MBVE). 3) Return on Equity (ROE) secara parsial tidak memiliki pengaruh signifikan terhadap Investment Opportunity Set (MBVE). Hal ini menunjukkan bahwa Return on Equity (ROE) yang tinggi belum tentu membuat investor atau calon investor untuk menanamkan modalnya di dalam perusahaan yang dapat meningkatkan nilai Investment Opportunity Set (MBVE). Sebaliknya, Return on Equity (ROE) yang rendah tidak berarti investor menghindari investasi di perusahaan tersebut. 4) Price to book value $(P B V)$ secara parsial memiliki pengaruh signifikan terhadap Investment Opportunity Set (IMBVE). Hipotesis yang menyatakan bahwa Price to book value (PBV) memiliki pengaruh yang signifikan terhadap Investment Opportunity Set (IMBVE) diterima. Hal ini 
menunjukkan bahwa Price to book value (PBV) perusahaan yang tinggi menjadi salah satu daya tarik investor atau calon investor untuk menanamkan modalnya di dalam perusahaan, sehingga dapat meningkatkan Investment Opportunity Set (MBVE).

Keterbatasandalampenelitianinisebagai berikut: 1) Hasil penelitian ini menunjukkan $70 \%$ pengaruh variabel independen dalam memengaruhi variabel dependen dan sisanya sebesar 30\% dipengaruhi oleh faktor-faktor lain yang tidak dimasukkan dalam model sehingga masih banyak variabel yang berpengaruh namun tidak dimasukkan dalam model ini. 2) Dalam penelitian ini terbatas pada saham yang termasuk dalam industri Property dan Real Estate yang terdaftar di Bursa Efek Indonesia periode 2007 - 2011 sehingga masih banyak perusahaan emiten lainnya yang belum masuk dalam penelitian ini.

Berdasarkan hasil analisis pembahasan serta beberapa kesimpulan tersebut maka penulis memberikan saran sebagai berikut : 1) Dalam penelitian mendatang perlu menambahkan menambah variabel fundamental maupun variabel ekonomi makro lainnya sebagai variabel independen, karena sangat dimungkinkan variabel lain yang tidak dimasukkan dalam penelitian ini berpengaruh kuat terhadap Investment Opportunity Set (MBVE). 2) Menambahkan rentang waktu yang lebih panjang sehingga nantinya diharapkan hasil yang diperoleh akan lebih dapat digeneralisasikan dan untuk memperluas penelitian serta menghasilkan analisis yang lebih baik. 3) Untuk penelitian selanjutnya sebaiknya menggunakan sampel yang berbeda dan tidak terbatas pada satu sektor industri saja, dengan demikian diharapkan akan memberikan kontribusi informasi yang lebih baik dan akurat untuk penelitian mendatang. 4) Penelitian selanjutnya, selain menggunakan faktor fundamental, sebaiknya juga memasukkan faktor dan teknikal, agar dapat memberikan gambaran yang lebih luas hal atas faktor-faktor yang memengaruhi IOS.

\section{Daftar Pustaka}

Dadri, Putu Terestiani, 2011. Pengaruh Investment Opportunity Set Dan Struktur Modal Terhadap Return Saham Pada Perusahaan Farmasi di Bursa Efek Indonesia, Tesis, Universitas Udayana, Denpasar.

Evana, Einde, 2009. Analisis Hubungan Investment Opportunity Set (IOS) Berdasarkan Nilai Pasar Dan Nilai Buku Dengan Realisasi Pertumbuhan, Universitas Lampung.

Hasnawati, S., 2005. Dampak Set Peluang Investasi Terhadap Nilai Perusahaan Publik di Bursa Efek Jakarta, Jurnal Riset Akuntansi Indonesia, 9 (2), 117-126.

Norpratiwi, A. M, 2007. Analisis Korelasi Investment Opportunity Set Terhadap Return Saham Pada Saat Pelaporan Keuangan Perusahaan. Jurnal Akuntansi Manajemen, 18 (1), 9-22.

Pagalung, Gagaring, 2003. Pengaruh Kombinasi Keunggulan dan Keterbatasan Perusahaan terhadap Set Kesempatan Investasi (IOS), Jurnal Riset Akuntansi Indonesia, vol.6, No.3, September 2003, Hal.249-263.

Wahyudi, U., dan Pawestri, H. P., 2006. Implikasi Struktur Kepemilikan Terhadap Nilai Perusahaan: Dengan Keputusan Keuangan Sebagai Variabel Intervening. Simposium Nasional Akuntansi 9 Padang. 